\title{
Correction to: Facile synthesis and capacitance properties of N-doped porous carbon/iron oxide composites through the single-step pyrolysis of coal-based polyaniline
}

\author{
Xiaoqin Wang ${ }^{1} \cdot$ Yufei Yang ${ }^{1} \cdot$ Yong Zhang ${ }^{1} \cdot$ Qiaoqin Li $^{1} \cdot$ Ming Gong ${ }^{1}$ • \\ Runlan Zhang ${ }^{1} \cdot$ Shanxin Xiong ${ }^{1}$
}

Published online: 12 October 2017

(C) Springer Science+Business Media, LLC 2017

\section{Correction to: J Porous Mater}

\section{DOI 10.1007/s10934-017-0497-8}

The original version of this article unfortunately contained the below equations in "Capacitance properties of NPC/ $\mathrm{Fe}_{\mathrm{x}} \mathrm{O}_{\mathrm{y}}$ composites" section which was not described, but was displayed in the article. The author wants to remove these equations.

$$
\begin{aligned}
& 3 \mathrm{Fe}+8 \mathrm{OH}^{-} \underset{+8 \mathrm{e}^{-}}{\stackrel{-8 \mathrm{e}^{-}}{\rightleftharpoons}} \mathrm{Fe}_{3} \mathrm{O}_{4}+4 \mathrm{H}_{2} \mathrm{O} \\
& 2 \mathrm{Fe}_{3} \mathrm{O}_{4}+2 \mathrm{OH}^{-} \underset{+2 \mathrm{e}^{-}}{\stackrel{-2 \mathrm{e}^{-}}{\rightleftharpoons}} 3 \mathrm{Fe}_{2} \mathrm{O}_{3}+\mathrm{H}_{2} \mathrm{O}
\end{aligned}
$$

The online version of the original article can be found under doi:10.1007/s10934-017-0497-8.

Xiaoqin Wang

wxq1230@163.com

$\triangle$ Shanxin Xiong

xiongsx689@sohu.com

1 College of Chemistry and Chemical Engineering, Xi' an

University of Science and Technology, Xi' an 710054,

People's Republic of China 